\title{
Nurse of a specialist team for diagnostics and treatment of syncope - a practical guide
}

\author{
Pielęgniarka specjalistycznego zespołu diagnostyki i leczenia omdleń - praktyczny przewodnik
}

\author{
Ewelina Kolarczyk ${ }^{1} \odot$, Izabella Uchmanowicz² ${ }^{\oplus}$, Agnieszka Młynarska ${ }^{1} \odot$, \\ Joanna Żółtańska ${ }^{3}$ (])
}

'Department of Gerontology and Geriatric Nursing, Faculty of Health Sciences in Katowice, Medical University of Silesia, Katowice/ Zakład Gerontologii i Pielegniarstwa Geriatrycznego, Wydział Nauk o Zdrowiu, Śląski Uniwersytet Medyczny w Katowicach 2 Division of Nursing in Internal Medicine Procedures, Department of Clinical Nursing, Faculty of Health Sciences, Wroclaw Medical University, Wroclaw/ Katedra Pielęgniarstwa Klinicznego, Wydział Nauk o Zdrowiu, Uniwersytet Medyczny we Wrocławiu.

${ }^{3}$ The Witelon State University of Applied Sciences in Legnica/ Państwowa Wyższa Szkoła Zawodowa im. Witelona w Legnicy

\author{
CORRESPONDING AUTHOR/AUTOR DO KORESPONDENCJI: \\ Ewelina Kolarczyk \\ Zakład Gerontologii i Pielęgniarstwa Geriatrycznego \\ Wydział Nauk o Zdrowiu w Katowicach \\ Śląski Uniwersytet Medyczny w Katowicach \\ Górnośląskie Centrum Medyczne im. prof. Leszka Gieca SUM \\ ul. Ziołowa 45/47, 40-635 Katowice \\ tel. 32-359-81-91. \\ e-mail: ekolarczyk@sum.edu.pl
}

STRESZCZENIE

Słowa kluczowe:

ABSTRACT

Key words:
PIELEGNIARKA SPECJALISTYCZNEGO ZESPOKU DIAGNOSTYKI I LECZENIA OMDLEN - PRAKTYCZNY PRZEWODNIK

Wprowadzenie. Współcześnie pielęgniarstwo postrzegane jest jako dyscyplina praktyczna, podlegająca procesom zmian na rzecz kompetencji i samodzielności zawodowej pielęgniarek. Upowszechnianie znaczenia roli specjalistycznego zespołu pielęgniarskiego zawartych w najnowszych wytycznych Europejskiego Towarzystwa Kardiologicznego (ESC) sprzyja budowaniu autonomii tego zawodu. Wraz z samodzielnością zawodową wiąże się wzrost odpowiedzialności i wymagań w zakresie kompetencji pielęgniarek. Dlatego dostrzega się potrzebę zebrania i podsumowania najważniejszych zasad postępowania w omdleniach będącymi kompendium wiedzy dla tej grupy zawodowej.

Cel pracy. Celem pracy było opracowanie praktycznego poradnika na temat aktywności i roli specjalistycznego zespołu pielęgniarskiego w opiece nad pacjentem z omdleniami.

omdlenia, pielęgniarstwo, zespół terapeutyczny

\section{NURSE OF A SPECIALIST TEAM FOR DIAGNOSTICS AND TREATMENT OF SYNCOPE - A PRACTICAL GUIDE}

Introduction. Nowadays, nursing is perceived as a practical discipline, subject to processes of change towards the competence and professional independence of nurses. Propagation of the importance of the role of a specialist nursing team featured in the latest guidelines of the European Society of Cardiology (ESC) conduces to build the autonomy of this profession. Professional independence carries the increment in responsibility and competence requirements. Therefore, there is a need to collect and summarise the most important rules for dealing with syncope.

Aim. The aim of the paper was to develop a practical guide on the activity and role of the specialist nursing team in the care of a patient with syncope.

syncope, nursing, therapeutic team 


\section{INTRODUCTION}

Syncope is one of the most common disease symptoms and accounts for around 1-6\% of all hospitalisations [1]. Approx. 25\% of syncope can result in surficial injuries [2]. It is estimated that about $15 \%$ of people had at least one syncope episode between 8 and 18 years of age $[3,4]$. Among adolescents and children, about $75 \%$ of all syncope are reflex (vasovagal) syncope [5]. Approximately $5 \%$ of adults experience the first syncope (reflexive) after the age of 40 [6]. As Framingham's research has shown, the second peak in the occurrence of (orthostatic) syncope occurs among older people after 70 years of age $[7,8]$. The latest ESC guidelines for the diagnosis and treatment of syncope from 2018 indicate a significant participation of a nurse in a specialist team for syncope treatment and diagnosis [9]. This is the first document that emphasizes and defines the role of the nurse in the specialist team for diagnosis and treatment of syncope, and also enables the nurse's independent professional activity in this medical area, which also entails expectations of the nurse to possess knowledge and skills in the assessment and therapy of syncope.

\section{AIM}

The goal of the paper was to develop a practical guide on the activity and role of the specialist nursing team caring for patients with syncope, which are described in detail in the latest guidelines of the European Society of Cardiology from 2018.

\section{DISCUSSION}

According to the ESC 2018 guidelines, specialist nursing staff is defined as „experienced practitioner [s] who [have] sufficient knowledge of history features and physical findings to recognize all major forms of TLOC, as well as syndromes of orthostatic intolerance". A nurse in the syncope diagnosis and treatment team is expected to be competent in the field of:

- Specialized clinical activity

- Collecting data on quality indicators

- Conducting audits and scientific research

- Education and training of patients with syncope and acting as a patients' spokesperson

- Consulting between representatives of individual medical disciplines and the devising, implementation of communication strategies between all stakeholders involved in the care of a patient with syncope

- Performing and interpreting specialized diagnostic tests.

\section{Nurse's role in differentiating between cases of loss of consciousness}

Loss of consciousness is a transient condition characterised by sudden onset, short duration, and spontaneous resolution. Syncope, however, is the loss of consciousness due to a generalized decrease in brain perfusion, unlike other causes of transient loss of consciousness (TLOC).
The notion of TLOC was introduced for the first time in the ESC 2009 manual to prevent confusing and abusing the denotations of syncope with each case of loss of consciousness [10].

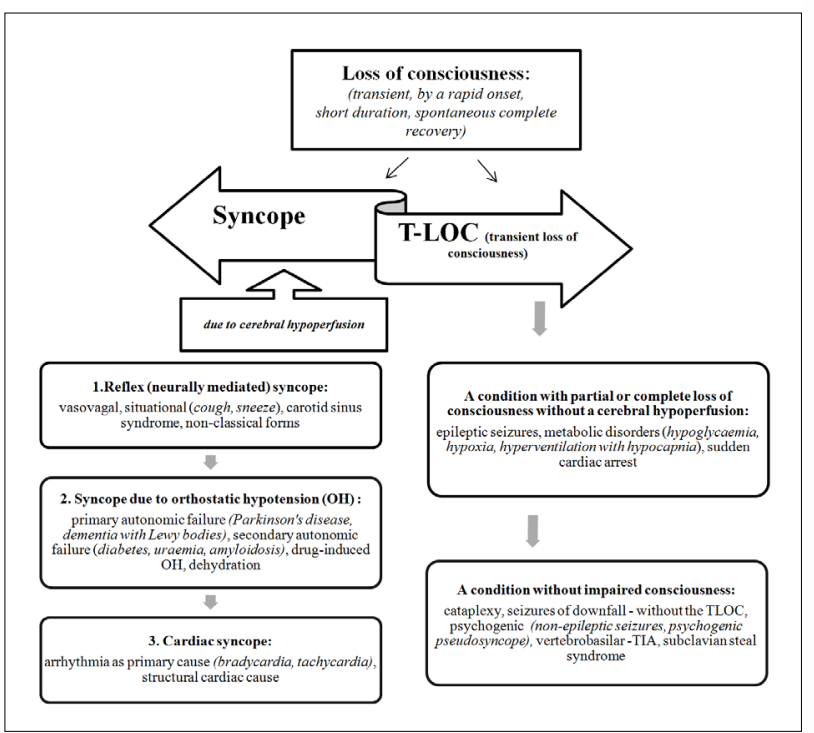

Fig 1. The classification of loss of consciousness in accordance with the ESC guidelines of 2009 and 2018

The nurse's specialist knowledge is important in the use of terms for awareness and consciousness in a patient with syncope. Both awareness and consciousness on medical grounds are the physiological states of the central nervous system, conditioned by the functioning of the cerebral cortex and the reticular system. Awareness is the realization of something, e.g. one's own behaviour, own actions or thoughts, i.e. it is the ability of recognition and assessment of oneself and the environment. In the case of consciousness, we are dealing with a state in which a person remains in contact with the environment, which does not necessarily mean that he/she is aware of, e.g. the time and place. It can be said that awareness is the highest level of consciousness, and the loss of consciousness is at the same time a total lack of awareness [11].

In approximately $23-50 \%$, it is possible to determine the cause of syncope already in the initial assessment, hence, it is important for the nurse to know the principles of using a standardised interview and medical history taking in syncope [12]. A thoroughly collected interview allows differentiation of syncope from other states of unconsciousness and provides important clinical indications suggesting or confirming the diagnosis. The interview should focus on the following questions: was the analysed event a temporary loss of consciousness, and if so - was this incident in fact syncopal? If we conclude that we are actually dealing with syncope, then the questions asked to the patient should be oriented on the underlying cause of the disease (family history, history of heart disease, parkinsonism, diabetes, epilepsy, antihypertensive drugs taken). The next step is to determine the risk of a cardiovascular incident, including the likelihood of death. A detailed algorithm for initial assessment and risk stratification in patients with syncope is included 
in the guidelines. When conducting an interview, the nurse should not omit questions regarding situations in which unconsciousness occurred, prodromal symptoms, the course of the syncope and the circumstances in which the syncope subsided (Fig. 2). While conducting an interview in the initial assessment, the nurse should collect eyewitness accounts of the syncope and materials, if available, from any video recordings made by observers of this event.

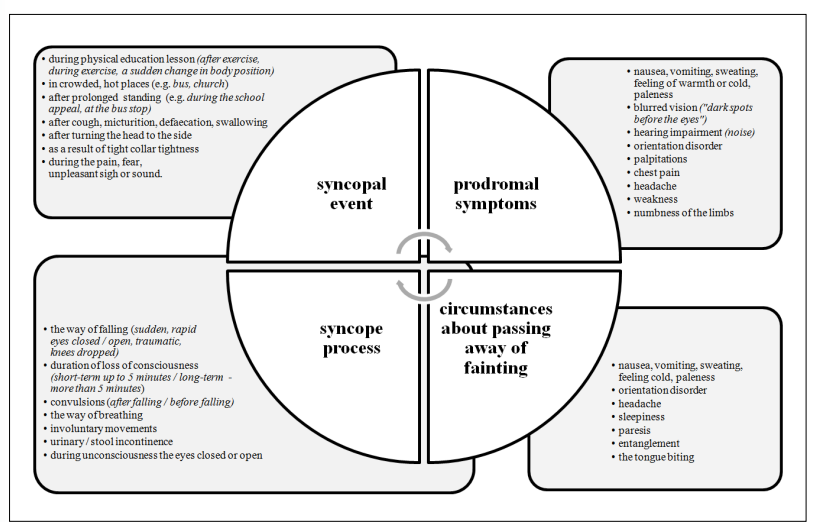

Fig 2. Interview in the initial assessment of syncope in accordance with ESC 2018 guidelines

The next step in initial diagnostics is to perform a physical examination, with a special assessment of the state of the circulatory system. Among others, the following actions are performed: 12-lead electrocardiographic (ECG) recording, blood pressure measurement (on both upper limbs, for $3 \mathrm{~min}$. during verticalization), pulse measurement. In a patient with the loss of consciousness, resting ECG analysis at the time of admission is one of the most important elements of the diagnostic process. A particular role in this regard plays a nurse who has a specialized course in the implementation and interpretation of electrocardiogram (ECG), who is able to determine already in the initial evaluation abnormalities indicating, e.g. the arrhythmic mechanism of syncope. Among other diagnostic tests falling within the scope of competence of nurses, as indicated in the guidelines of ESC, there is participation in conducting and monitoring specialist diagnostic tests (Fig. 3). Autonomous system assessment tests which can be performed by a nurse include, a.o. Valsalva maneuver (forced exhalation with the glottis closed) and deep breathing test (deep breathing at a rate of 6 breaths per minute, measured for 3 minutes). The nurse's active

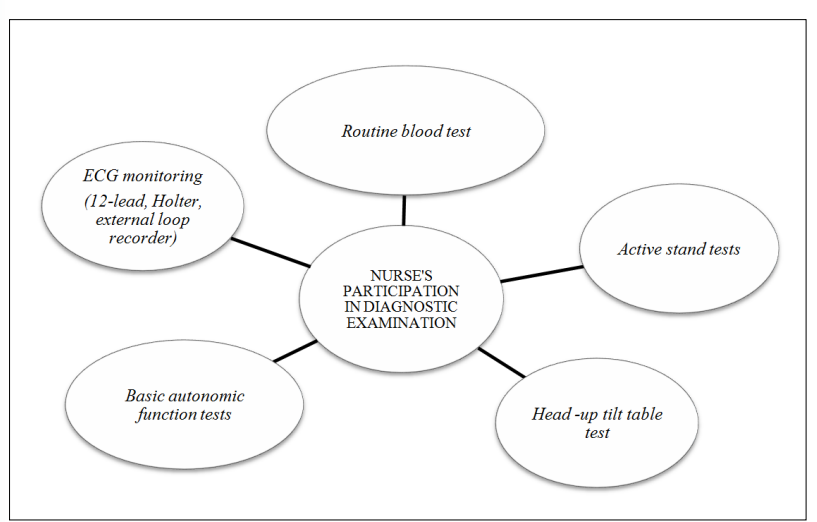

Fig 3. The role of clinical nurse's specialist in performing procedures and diagnostic examination in accordance with ESC 2018 guidelines participation in the diagnosis of syncope also includes conducting orthostatic tests such as: active standing test or tilt test. The active standing test enables to identify orthostatic hypotension or postural orthostatic tachycardia syndrome (POTS). In this test, the patient adopts a standing position after a 10-15 minute rest in a lying position. Blood pressure measurements are then taken at 1, 2, 3 and 10 minutes after verticalization. The occurrence of symptoms and abnormalities during the active standing test is recorded in the examination protocol. A more complex version of the active standing test is the tilt test (Head -up Tilt Table Test), which is mainly used in the diagnosis of reflex syncope (especially vasovagal). The tilt test is performed in the morning, on an empty stomach, in a quiet and warm room in which the patient's position is changed using a movable table, to a $60-70^{\circ}$ of the table tilt angle, depending on the type of test protocol used (Italian, Westminster, with provocation or without pharmacological induction). During the tilt test, the patient's heart rate, blood pressure and behaviour are recorded [13].

Both, the nurse in a syncope diagnosis and treatment centre and a nurse working in the emergency room should have special competence in the syncope procedure. Observation of the patient with syncope in the hospital emergency unit and the decision on further proceedings, including hospitalisation of the patient, involve determining a high risk of death assessment, which include:

- organic heart disease

- chronic disease with severe course

- syncope when sitting, lying down, straining

- occurrence of palpitations when syncope occurs

- no preceding signs of syncope

- electrocardiographic recording indicating: inadequate sinus bradycardia, sinoatrial block, QRS pre-excitation syndrome, supraventricular tachycardia, paroxysmal atrial fibrillation, hereditary arrhythmogenic disease (Brugada syndrome, QT prolonged syndrome) and arrhythmogenic right ventricular dysplasia (ARVC)

- suspected malfunction of the implanted cardiac electrostimulation device

Pursuant to the Article 4 of the Act on the Nurse and Midwife Profession of 2011, practicing the profession of a nurse consists in providing health education and health promotion services [14]. ESC guidelines also indicate the participation of a specialist nursing team in the education and training of patients with syncope. Health education and lifestyle modification are important in the treatment of syncope caused by orthostatic hypotension and reflex syndrome. In these cases, the purpose of educating patients with syncope is to explain the mechanism of syncope to the patient and their carers and to provide information about the benign nature of the disease. It is important to inform about potential factors that may provoke the loss of consciousness and to teach the patient and their carer the correct proceeding in case of the occurrence of symptoms preceding syncope [5]. 


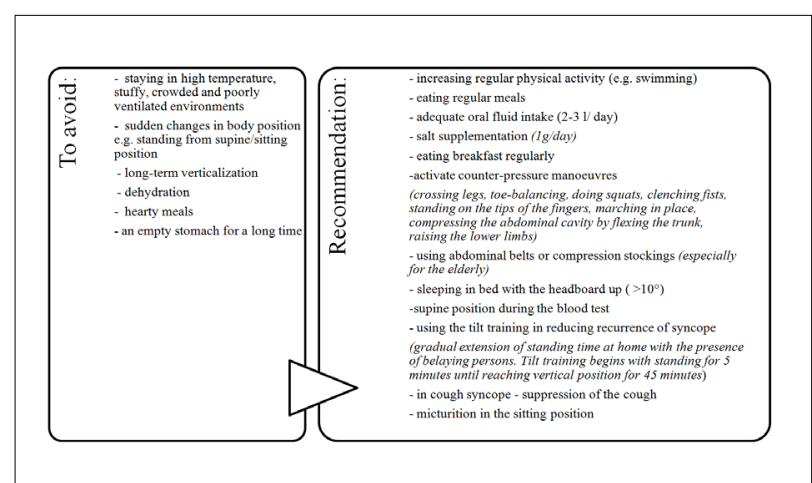

Fig 4. Educational recommendations in orthostatic and reflex syncope in accordance with ESC 2018 guidelines

cope with the disease and prevent its recurrence. Through educational activities, the nurse shapes the patient's health-promoting skills and their correct attitude towards strengthening health (e.g. changing lifestyle, recognizing prodromal symptoms, etc.). Educating patients with reflex or orthostatic syncope helps prevent the recurrence of syncope episodes and the risk of physical injuries sustained during syncope, as well as increases the quality of life of the sick person $[5,10,15]$.

\section{Professional development and postgraduate education of nurses}

The new ESC 2018 guidelines for diagnosis and treatment of syncope provide opportunities for both professional and scientific development of a nurse. The question should be considered, what forms of postgraduate education increase the qualifications of a nurse to work in a specialist team for the treatment and diagnosis of syncope? Among the fields of nursing specialisations applicable in syncope, we can enumerate specialisation in internal medicine, emergency, as well as geriatric and pediatric nursing. The qualification courses that fall within the competence of the nurse of the specialist team for diagnosis and treatment of syncope include the qualification course for nurses in the fields of cardiological, neurological, emergency, geriatric and paediatric nursing [16]. The ESC guidelines require a nurse for diagnosis and treatment of syncope the skills in the scope of conducting, performing and interpreting structured interviews and standard electrocardiographic recording (ECG). This competence is enabled by the specialist course of performance with interpretation of the electrocardiographic record and the medical history and physical examination. The latest ESC guidelines indicate the competence of specialist nursing staff in conducting audits and scientific research. This creates the opportunity to implement the idea of Evidence-based Nursing Practice, i.e. nursing practice based on scientific evidence, which is necessary for the development of a modern and effective professional work of a nurse.

\section{SUMMARY}

In summary, the latest guidelines in the management of syncope give development opportunities and raise the importance of a nurse in the therapeutic team. Specialized nursing staff plays an important role in developing and implementing strategies for patients with syncope. The nurse plays a pivotal role in patient education and promotion of health-promoting behaviours, as well as in the communication process between the patient, his family and the entire diagnostic-therapy team. On this account is the involvement of the nurse so crucial in raising the knowledge and skills necessary to assess and treat syncope and other forms of transient loss of consciousness.

\section{Pielęgniarka specjalistycznego zespołu diagnostyki i leczenia omdleń - praktyczny przewodnik}

\section{WPROWADZENIE}

Omdlenie jest jednym z najczęściej występujących objawów chorobowych i stanowi przyczynę około 1-6\% wszystkich hospitalizacji [1]. Ok. $25 \%$ omdleń może skutkować powierzchniowymi obrażeniami ciała [2]. Szacuje się, że ok. 15\% osób, przebyło co najmniej jeden epizod omdlenia w okresie pomiędzy 8. a 18. rokiem życia $[3,4]$. Wśród dzieci i młodzieży ok.75\% wszystkich omdleń stanowią omdlenia odruchowe (wazowagalne) [5]. Ok. 5\% osób dorosłych doświadcza pierwszego omdlenia (odruchowego) po ukończeniu 40 r.ż. [6]. Jak wykazały badania Framingham, drugi szczyt występowania omdleń (ortostatycznych) zachodzi wśród osób starszych po 70 r.ż. [7,8]. Najnowsze wytyczne ESC dotyczące rozpoznawania i leczenia omdleń z 2018 roku wskazują na istotny udział pielęgniarki w specjalistycznym zespole leczenia i diagnostyki omdleń [9]. Jest to pierwszy dokument, który akcentuje i określa rolę pielęgniarki w specjalistycznym zespole diagnostyki i leczenia omdleń, a także umożliwia samodzielną aktywność zawodową pielęgniarki w tym obszarze medycznym co równocześnie wiąże się z oczekiwaniami wobec pielęgniarki do posiadania wiedzy oraz umiejętności w zakresie oceny i terapii omdleń.

\section{CEL PRACY}

Celem pracy było opracowanie praktycznego poradnika na temat aktywności i roli specjalistycznego zespołu pielęgniarskiego $\mathrm{w}$ opiece nad pacjentem $\mathrm{z}$ omdleniami, które szczegółowo opisane zostały w najnowszych wytycznych z 2018 r Europejskiego Towarzystwa Kardiologicznego. 


\section{OMÓWIENIE}

Zgodnie wytycznymi ESC 2018 specjalistyczny personel pielęgniarski definiowany jest jako „doświadczony personel dysponujacy wystarczajaca wiedza na temat wywiadów i badania przedmiotowego, aby móc rozpoznać wszystkie główne postacie omdleń i przemijajacej utraty przytomności (T-LOC), a także zespoły nietolerancji ortostatycznej" [10]. Od pielęgniarki zespołu diagnostyki i leczenia omdleń oczekuje się kompetencji w zakresie:

- Wyspecjalizowanej aktywności klinicznej

- Zbierania danych na temat wskaźników jakości

- Prowadzenia audytów i badań naukowych

- Edukacji i szkolenia pacjentów z omdleniami oraz występowanie w roli rzeczników pacjentów

- Konsultacji między przedstawicielami poszczególnych dyscyplin medycznych oraz opracowywanie, realizację strategii komunikacyjnych między wszystkimi stronami uczestniczącymi w opiece nad pacjentem $\mathrm{z}$ omdleniami

- Wykonywania i interpretacji specjalistycznych badań diagnostycznych.

Utrata przytomności stanowi stan przejściowy, który charakteryzuje się nagłym początkiem, krótkim czasem trwania oraz samoistnym ustąpieniem. Omdlenie zaś, jest utratą przytomności w wyniku uogólnionego zmniejszenia perfuzji mózgu, w odróżnieniu od innych przyczyn przejściowych utrat przytomności (transient loss of consciousness, T-LOC). Pojęcie T-LOC po raz pierwszy wprowadzone zostało w wytycznych ESC z 2009 roku w celu zapobiegnięcia mylenia i nadużywania określeń omdlenia z każdym epizodem utraty przytomności [10].

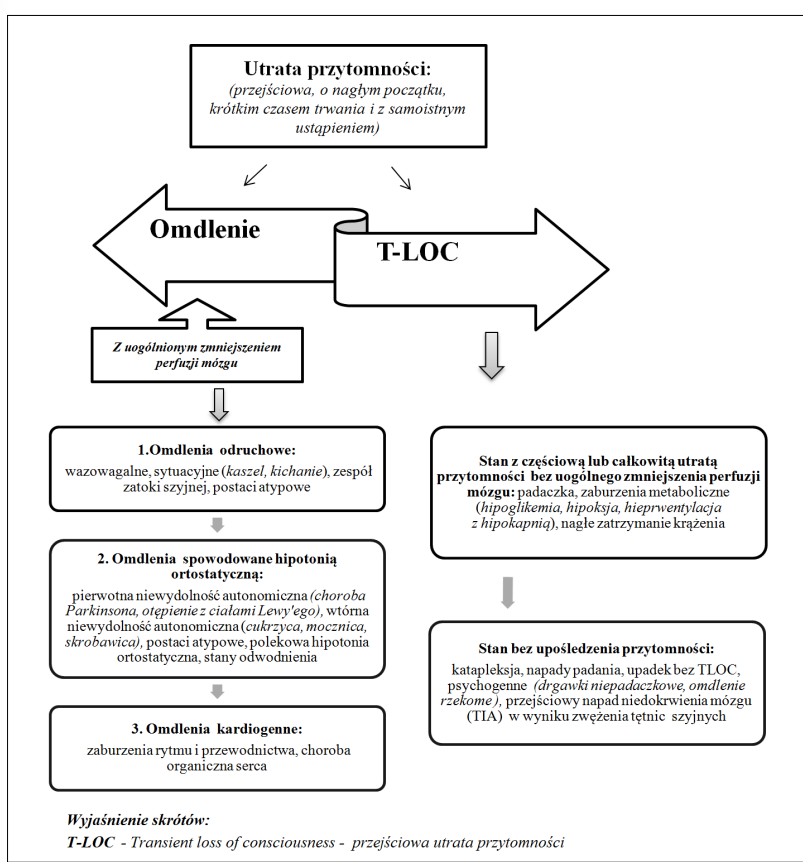

Ryc 1. Klasyfikacja utrat przytomności zgodnie z wytycznymi ESC z 2009 i $2018 \mathrm{r}$.
Ważna jest specjalistyczna wiedza pielęgniarki w stosowaniu określeń dotyczących świadomości i przytomności u pacjenta z omdleniem. Zarówno świadomość jak i przytomność na gruncie medycznym są stanem fizjologicznym ośrodkowego układu nerwowego, uwarunkowanego funkcjonowaniem kory mózgowej i układu siatkowatego. Świadomość jest to zdawanie sobie sprawy z czegoś np.: z własnego zachowania, własnych czynów czy myśli, czyli jest to zdolność do poznawania oraz oceny własnej osoby i otoczenia. W przypadku przytomności, mamy do czynienia ze stanem, w którym osoba pozostaje w kontakcie $\mathrm{z}$ otoczeniem co nie musi oznaczać, że ma świadomość np. co do czasu i miejsca. Można powiedzieć, że świadomość to najwyższy stopień przytomności, a utrata przytomności jest zarazem całkowitym brakiem świadomości [11].

U ok. 23-50\% możliwe jest określenie przyczyny omdlenia już w ocenie wstępnej, dlatego ważne jest aby pielęgniarka znała zasady zastosowania standaryzowanego badania podmiotowego i przedmiotowego w omdleniach [12]. Dokładnie zebrany wywiad pozwala na zróżnicowanie omdleń $\mathrm{z}$ innymi stanami utraty przytomności oraz dostarcza ważne wskazówki kliniczne sugerujące bądź potwierdzające rozpoznanie. Badanie podmiotowe powinno skupiać się na następujących pytaniach: czy analizowane zdarzenie rzeczywiście było przejściową utratą przytomności, a jeśli tak - to czy incydent ten był rzeczywiście omdleniem? Jeżeli stwierdzamy, że istotnie mamy do czynienia $\mathrm{z}$ omdleniem, to zadawane pacjentowi pytania powinny być zorientowane na podłoże choroby (wywiad rodzinny, przebyte choroby serca, parkinsonizm, cukrzyca, padaczka, przyjmowane leki hipotensyjne). Kolejnym krokiem jest określenie ryzyka incydentu sercowo-naczyniowego, $\mathrm{w}$ tym również prawdopodobieństwa wystąpienia zgonu. Szczegółowy algorytm oceny wstępnej i stratyfikacji ryzyka u pacjentów z omdleniem zawarty jest w wytycznych. Pielęgniarka przeprowadzając wywiad, nie powinna pominąc pytań dotyczących sytuacji, w których doszło do utraty przytomności, objawów prodromalnych, przebiegu omdlenia oraz okoliczności w jakich omdlenie ustąiłiło (Ryc.2). W ocenie wstępnej, pielęgniarka przeprowadzając wywiad, powinna zebrać relację naocznych świadków omdlenia oraz materiały $z$ ewentualnych nagrań wideo wykonanych przez obserwatora tego zdarzenia.

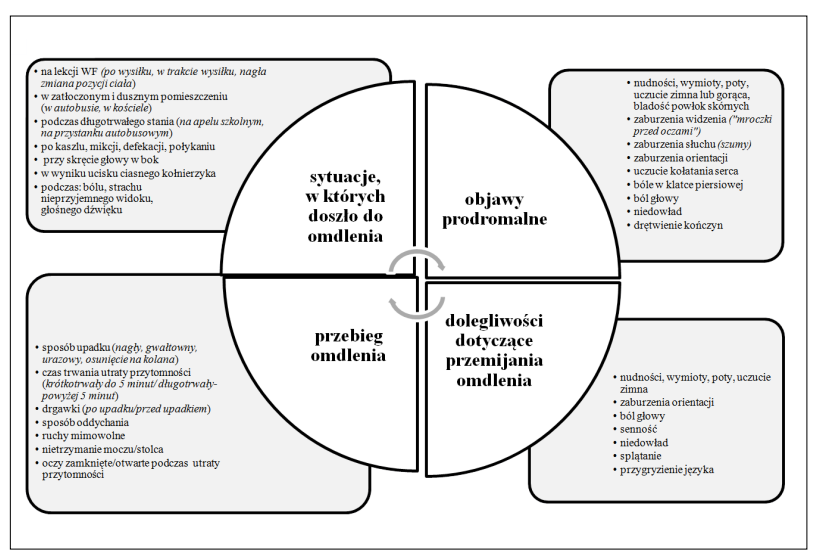

- Ryc 2. Badanie podmiotowe w ocenie wstępnej omdleń zgodnie z wytycznymi ESC 2018 r. 
Kolejnym krokiem w diagnostyce wstępnej jest wykonanie badania przedmiotowego, ze szczególnym uwzględnieniem oceny stanu układu krążenia. Wykonuje się m. in.: 12-odprowadzeniowy zapis elektrokardiograficzny (EKG), pomiar ciśnienia tętniczego krwi (na obu kończynach górnych, przez $3 \mathrm{~min}$. podczas pionizacji), pomiar tętna. Jednym $z$ najważniejszych elementów procesu diagnostycznego, u chorego z utratą przytomności, jest analiza spoczynkowego zapisu EKG przy przyjęciu. Szczególną rolę, $\mathrm{w}$ tym zakresie, odgrywa pielęgniarka posiadająca kurs specjalistyczny z zakresu wykonania i interpretacji zapisu elektrokardiograficznego, która jest w stanie już we wstępnej ocenie określić nieprawidłowości wskazujące np.: na mechanizm arytmiczny omdlenia. Wśród innych badań diagnostycznych wchodzących w zakres kompetencji pielęgniarki określonych w wytycznych ESC, jest m. in. udział $\mathrm{w}$ przeprowadzeniu i monitorowaniu specjalistycznych testów diagnostycznych (Ryc.3). Do testów oceny czynności układu autonomicznego, które może wykonać pielęgniarka należy min. próba Valsalvy (wykonanie natężonego wydechu przy zamkniętej głośni) oraz test głębokiego oddychania (głębokie oddychanie, z częstością 6 oddechów na minutę, mierzone przez 3 minuty). Aktywny udział pielęgniarki w diagnostyce omdleń obejmuje również przeprowadzenie testów ortostatycznych takich jak: test aktywnego stania lub test pionizacyjny (tilt test). Test aktywnego stania pozwala rozpoznać hipotonię ortostatyczną lub posturalną tachykardię ortostatyczną (postural orthostatic tachykardia syndrome- POTS). Badanie to polega na przyjęciu przez chorego pozycji stojącej po uprzednim 10-15 minutowym odpoczynku w pozycji leżącej. Następnie dokonuje się pomiarów ciśnienia tętniczego krwi w 1', 2', 3' oraz w 10 minucie po pionizacji. Wystąpienie objawów i nieprawidłowości podczas testu aktywnego stania odnotowuje się w protokole badania. Wersją bardziej złożoną testu aktywnego stania jest test pionizacyjny (tilt test), który wykorzystywany jest głównie w diagnostyce omdleń odruchowych (zwłaszcza wazowagalnych). Test pionizacyjny wykonuje się godzinach porannych, na czczo, w cichym i ciepłym pomieszczeniu, w którym za pomocą ruchomego stołu, dokonuje się zmiany pozycji pacjenta do kąta $60-70^{\circ}$ nachylenia stołu w zależności od rodzaju zastosowanego protokołu badania (Włoski, Westminsterski, z prowokacją lub bez prowokacji farmakologicznej). Podczas testu pionizacyjnego

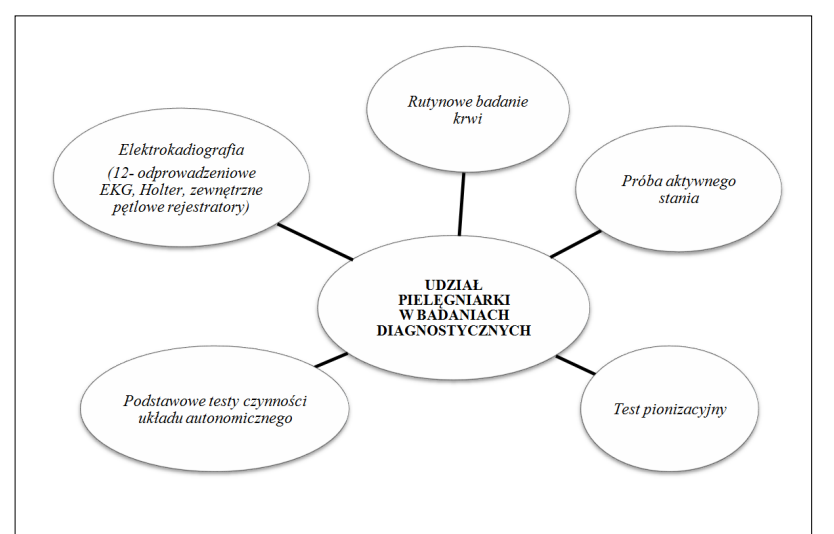

Ryc 3. Udział pielęgniarki w wykonywaniu procedur i badań diagnostycznych zgodnie z wytycznymi ESC $2018 \mathrm{r}$. rejestruje się czynność akcji serca, ciśnienie tętnicze krwi oraz zachowanie się pacjenta [13].

Szczególne kompetencje w postępowaniu w omdleniach powinna mieć nie tylko pielęgniarka zespołu ośrodka diagnostyki i leczenia omdleń, ale również pielęgniarka pracująca na izbie przyjęć oddziału ratunkowego. Obserwacja pacjenta $\mathrm{z}$ omdleniem w szpitalnym oddziale ratunkowym i decyzja o dalszym postępowaniu, w tym o hospitalizacji pacjenta, wiąże się z określeniem oceny wysokiego ryzyka zgonu, do którego zalicza się:

- organiczna choroba serca

- choroba przewlekła z ciężkim przebiegiem

- omdlenie podczas siedzenia, leżenia, wysiłku

- wystąpienie kołatania serca w trakcie omdlenia

- brak objawów zwiastujących omdlenie

- badanie elektrokardiograficzne wskakujące na: nieadekwatną bradykardię zatokową, blok zatokowo-przedsionkowy, preekscytację zespołu QRS, częstoskurcz nadkomorowy, napadowe migotanie przedsionków, dziedziczną chorobę arytmogenną (zespół Brugadów, zespół wydłużonego odstępu QT) oraz na arytmogenną kardiomiopatię prawej komory - ARVC)

- podejrzenie nieprawidłowego funkcjonowania wszczepionego urządzenia do elektrostymulacji serca.

Zgodnie $\mathrm{z}$ artykułem 4 ustawy o zawodzie pielęgniarki i położnej z 2011 roku, wykonywanie zawodu pielęgniarki polega na udzielaniu świadczeń z zakresu edukacji zdrowotnej i promocji zdrowia [14]. Również wytyczne ESC wskazują na udział specjalistycznego zespołu pielęgniarskiego w edukacji i szkoleniu pacjentów z omdleniami. Edukacja zdrowotna i modyfikowanie stylu życia ma istotne znaczenie w terapii omdleń spowodowanych hipotensją ortostatyczną oraz zespołem odruchowym. W tych przypadkach celem edukacji pacjentów $\mathrm{z}$ omdleniem jest wyjaśnienie pacjentowi i jego opiekunom mechanizmu omdlenia oraz udzielenie informacji o łagodnym charakterze choroby. Ważne jest poinformowanie o potencjalnych czynnikach, które mogą sprowokować utratę przytomności oraz nauczenie pacjenta i jego opiekuna właściwego postępowania w przypadku pojawienia się objawów zwiastujących omdlenie [5].

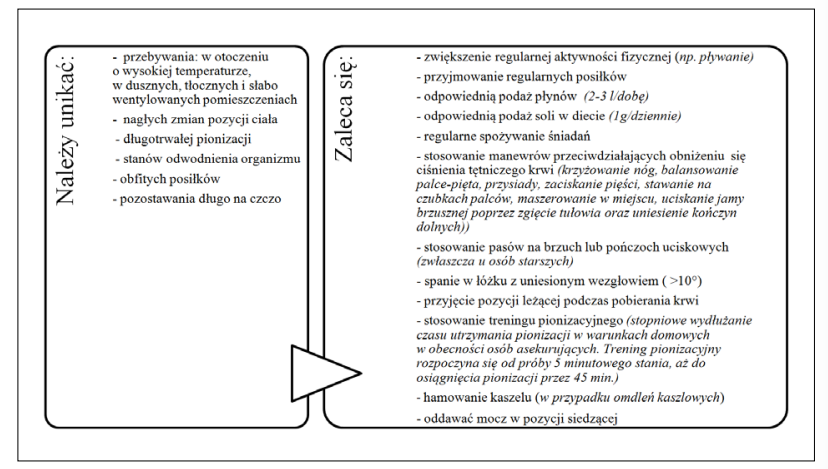

Ryc 4. Zalecenia edukacyjne w omdleniach ortostatycznych i odruchowych zgodnie z wytycznymi ESC 2018 r. 
Działania edukacyjne integralnie łączą się z istotą pielęgnowania, którego celem jest pomaganie pacjentowi w radzeniu sobie $\mathrm{z}$ chorobą i zapobieganie występowaniu nawrotom omdleń. Poprzez działania edukacyjne, pielęgniarka kształtuje w pacjencie umiejętności sprzyjające zdrowiu oraz prawidłowe postawy pacjenta ukierunkowane na wzmacnianie zdrowia (np. zmiana stylu życia, rozpoznawanie objawów prodromalnych). Poprzez edukację pacjenta $\mathrm{z}$ omdleniami odruchowymi lub ortostatycznymi, zapobiega się nawrotom epizodów omdleń, ryzyku urazów fizycznych doznanych podczas omdlenia, a także poprawia się jakość życia chorego $[5,10,15]$.

Nowe wytyczne ESC z 2018 r., do spraw diagnostyki i leczenia omdleń, dają możliwość zarówno rozwoju zawodowego jak i naukowego pielęgniarki. Należy zastanowić się jakie formy kształcenia podyplomowego podnoszą kwalifikacje pielęgniarki do pracy w specjalistycznym zespole leczenia i diagnostyki omdleń? Wśród dziedzin specjalizacji pielęgniarskich mających zastosowanie $\mathrm{w}$ omdleniach można zaliczyć specjalizację z zakresu pielęgniarstwa internistycznego, ratunkowego, a także geriatrycznego i pediatrycznego. Do kursów kwalifikacyjnych, które wchodzą w zakres kompetencji pielęgniarki specjalistycznego zespołu diagnostyki i leczenia omdleń należy kurs kwalifikacyjny dla pielęgniarek w dziedzinach pielęgniarstwa kardiologicznego, neurologicznego, ratunkowego, geriatrycznego oraz pediatrycznego [16]. Wytyczne ESC wymagają od pielęgniarki zespołu diagnostyki i leczenia omdleń umiejętności z zakresu przeprowadzania, wykonywania i interpretacji usystematyzowanych wywiadów oraz standardowego zapisu EKG. Takie kompetencje umożliwia kurs specjalistyczny wykonania i interpretacji zapisu elektrokardiograficznego oraz badania przedmiotowego i podmiotowego. Najnowsze wytyczne ESC, wskazują na kompetencje specjalistycznego personelu pielęgniarskiego $\mathrm{w}$ zakresie prowadzenia audytów i badań naukowych. Stwarza to możliwość wdrażania idei Evidence-based Nursing Practice, czyli praktyki pielęgniarskiej opartej na dowodach naukowych, która jest konieczna dla rozwoju nowoczesnej i efektywnej pracy zawodowej pielęgniarki.

\section{PODSUMOWANIE}

Podsumowując, najnowsze wytyczne ESC do spraw postępowania w omdleniach, należy wskazać, że dają możliwość rozwoju oraz podnoszą znaczenie pielęgniarki $\mathrm{w}$ zespole terapeutycznym. Specjalistyczny personel pielęgniarski odgrywa istotną rolę w opracowaniu i realizacji strategii postępowania u pacjentów z omdleniami. Pielęgniarka pełni zasadniczą funkcję $\mathrm{w}$ edukacji pacjentów i promocji zachowań prozdrowotnych oraz $\mathrm{w}$ procesie komunikacji między pacjentem, jego rodziną oraz z całym zespołem ośrodka diagnostyczno-terapeutycznego. Dlatego tak ważne jest zaangażowanie pielęgniarki w podnoszenie wiedzy i umiejętności niezbędnych do oceny i leczenia omdleń oraz innych postaci przemijającej utraty przytomności, czemu ma służyć niniejszy poradnik.

\section{ORCID}

Ewelina Kolarczyk (iD) https://orcid.org/0000-0002-8837-4087

Izabella Uchmanowicz (iD https://orcid.org/0000-0001-5452-0210

Agnieszka Młynarska (iD https://orcid.org/0000-0003-4009-0613

\section{REFERENCES/PIŚMIENNICTWO}

1. Wieling W, Gazeboom KS, Saul JP. Reflex syncope in children and adolescents. Heart. 2004;90(90): 1094-1000.

2. KułakowskiP, Lelonek M, Kryński T, i wsp. Prospective evaluation of diagnostics workup in syncope patients: result of the PL-US registry. Europace. 2010;12 (2): 230-239.

3. Driscoll DJ, Jacobsen SJ, Porter CJ, i wsp. Syncope in children and adolescents. Journal of the American College of Cardiology. 1997;29(5): 1039-1045.

4. Nowakowska E, Morka A, Szydłowski L. Omdlenia u dzieci i młodzieży jako nagła, przemijająca,krótkotrwałaisamoistnieustępującautrataświadomościspowodowana zmniejszeniem perfuzji mózgu. Pediatria i Medycyna Rodzinna. 2014;10(3): 234-241.

5. Stańko A, Sabiniewicz R, Mazurkiewicz-Bełdzińska M, i wsp. Omdlenia w pediatrii. Standardy Medyczne Pediatria. 2016;13:808-818.

6. Colman N, Nahm K, Ganzeboom KS, i wsp. Epidemiology of reflex syncope. Clinical Autonomic Research. 2004;14(1): i9-i17.

7. Savage DD, Corwin L, McGee DL, i wsp. Epidemiologic Features of Isolated Syncope: The Framingham Study. Storke. 1985;16(4): 626-629.

8. Soteriades ES, Evans JC, Larson MG, i wsp. Incidence and prognosis of syncope. New England Journal of Medicine. 2002;347: 878-885.

9. Brignole M, Moya A, de Lange FJ, i wsp. 2018 ESC Guidelines for the diagnosis and management of syncope. European Heart Journal. 2018:39: 1883-1948.

10. Moya A, Sutton R, Brignole M, i wsp. Wytyczne Europejskiego Towarzystwa Kardiologicznego dotyczące diagnostyki i postępowania w omdleniach. Kardiologia Polska. 2009;67(12): 545-593.

11. Słownik Języka Polskiego https://sjp.pwn.pl/sjp/swiadomosc;2528182. html; https://sjp.pwn.pl/szukaj/przytomno\%C5\%9B\%C4\%87.html. Data dostępu: 20.03.2020

12. Croci F, Brignole M, Alboni P, Menozzi C, i wsp. The application of a standardized strategy of evaluation in patients with syncope refferend to three Syncope Units. Europace. 2002;4: 351-356.

13. Ptaszyński $P$, Kaczmarek $K$, Wranicz J. Ocena funkcji układu autonomicznego w kardiologii. Postępy Nauk Medycznych. 2014;27(7): 439-446.

14. Ustawa 0 zawodach pielęgniarki i położnej z dnia 15 lipca 2011 r.; Dz. U. 2011; $n$ r 174 poz.1039.http://prawo.sejm.gov.pl/isap.nsf/download.xsp/WDU20111741039/U/ D20111039Lj.pdf . Data dostępu: 29.10.2019.

15. Kurpesa M. Omdlenia u młodocianych i młodych dorosłych. Kardiologia po Dyplomie. 2012;11(1): 43-48

16. Rozporządzenie Ministra Zdrowia z dn.12.12.2013 r. w sprawie wykazu dziedzin pielęgniarstwa oraz dziedzin mających zastosowanie w ochronie zdrowia, w których może być prowadzona specjalizacja i kursy kwalifikacyjne. Poz. 1562. http://prawo.sem.gov.pl/isap.nsf/download.xsp/WDU20130001562/0/D20131562.pdf. Data dostępu: 20.03 .2020

Manuscript received/Praca zgłoszona do czasopisma: 21.03.2020

Manuscript accepted/Praca zaakceptowana do druku: 08.07.2020

Translation/Tłumaczenie: Elżbieta Rutkowska, rutkowska.filon@gmail.com (tłumaczenie artykułu); Ewelina Kolarczyk, (tłumaczenie rycin) 